\title{
A muskingum model based on unit-step and transfer function approach for prediction of direct runoff hydrographs from a small watershed
}

S.N. BANSUDE, G.L. CHUNALE AND A.A. SHINDE

See end of the Paper for authors' affiliation

Correspondence to :

\section{S.N. BANSUDE}

Department of Soil and Water Conservation Engineering, Dr. Panjabrao Deshmukh Krishi Vidyapeeth, AKOLA (M.S.) INDIA

Email : bansude.sushilkumar@ gmail.com
ABSTRACT : The hydrological investigation was carried out to develop a mathematical expression for Muskingum model on the basis of application of unit-step function for prediction of direct runoff hydrographs from Shenda Park watershed, Kolhapur of Maharashtra state considering it to be a lumped, linear and timeinvariant system. Generally the ordinates of direct runoff are obtained directly as the inverse Laplace transform of the product of Laplace transform of the input and the transfer function of the system. The value of model parameter, storage constant $(\mathrm{K})$ was estimated, which was found to be 0.37 (hr). Direct runoff hydrographs were developed against three values of weighing factor, $X=0.00$ (reservoir routing), $\mathrm{X}=0.05$ (channel routing), and $\mathrm{X}=0.10$ (channel routing). Performance evaluation of developed model in determining direct runoff hydrograph ordinates was evaluated using various statistical indices. For weighing factor, $X=0.00$, the overall average values of co-efficient of efficiency (CE), co-efficient of correlation (R), special correlation co-efficient $\left(\mathrm{R}_{\mathrm{s}}\right)$, root mean square error (RSME) and percentage absolute deviation in peak flow $\left(\mathrm{PAD}_{\mathrm{p}}\right)$ and runoff volume $\left(\mathrm{PAD}_{\mathrm{v}}\right)$ were found to be $0.902,0.962,0.926,0.0013$ and 17.66 and 2.65 , respectively. Based on all the evaluation criteria, model can be easily applied for the prediction of direct runoff hydrograph ordinates for the study watershed.

- KEY WORDS : Direct runoff hydrograph, Muskingum model, Laplace transform

— HOW TO CITE THIS PAPER : Bansude, S.N., Chunale, G.L. and Shinde, A.A. (2014). A muskingum model based on unit-step and transfer function approach for prediction of direct runoff hydrographs from a small watershed. Internat. J. Agric. Engg., 7(2) : 450-455. 